\title{
Anisotropic Geomechanical Characterization of Sojuko Field, Shallow Offshore, Niger Delta
}

\author{
Difference O. Ogagarue ${ }^{1^{*}} \quad$ Mary T. Olowokere ${ }^{2}$ \\ 1.Department of Earth Sciences, Federal University of Petroleum Resources, Effurun, Nigeria \\ 2.Department of Geology, Obafemi Awolowo University, Ile-Ife, Nigeria
}

\begin{abstract}
Borehole stability and hydraulic fracture issues are a major concern in the economic development of hydrocarbon reserves especially for deep targets which require drilling below well control. Characterizing geomechanical properties along a wellbore provides understanding of the vertical heterogeneity in the mechanical properties of the rocks, both in reservoirs and the bounding non-reservoir formations, and is critical to the operational planning and design of stable wellbores to successfully drill, complete and exploit proven hydrocarbon reserves even at shallow depths. In this work, velocity anisotropy, assuming vertical transverse isotropy with vertical axis of symmetry, was utilized to evaluate important geomechanical properties which include Young's modulus and the Poisson's ratio, in order to accurately determine rock strength and in situ horizontal stresses using geophysical well logs obtained from some wells in the Sojuko field, shallow Niger Delta offshore. The aim was to determine accurate parameters, by consideration of anisotropy, to aid well design and prevent formation failure during future developmental drilling in the field, and the subsequent landing of wells. The starting point was the estimation of the Thomsen's delta anisotropic parameter from analysis of well and seismic interval velocities at a well location, which then aided derivation of the epsilon and gamma anisotropic parameters. The three anisotropy parameters were used in combination with bulk density and sonic log data to determine stiffness constants for the estimation of the geomechanical properties, which subsequently enabled the determination of rock strength and in situ stresses around the wellbore for analysis of rock failure and mudweight requirements for safe and cost effective drilling of the well. Computed in situ minimum horizontal stress in the area varies with depth from $727 \mathrm{psi}$ to $7,500 \mathrm{psi}$, with an average gradient of $0.69 \mathrm{psi} / \mathrm{ft}$, while the maximum horizontal stress is about $12.27 \%$ higher on the average. Minimum average safe drilling mudweight for the well is $0.529 \mathrm{psi} / \mathrm{ft}$, giving an average overbalance of $655 \mathrm{psi}$ mud pressure which is relatively higher in shale than sands. Predicted safe drilling mudweight window ranges from $0.529 \mathrm{psi} / \mathrm{ft}$ to $0.713 \mathrm{psi} / \mathrm{ft}$. Comparison of the results with geomechanical data computed with isotropic assumption shows that the nonconsideration of anisotropy results in under prediction of geomechanical data in subsurface formations where velocity anisotropy is present. This has serious safety and cost implication during drilling as most of the Niger Delta deep targets are located in geopressured formations where velocity anisotropy is a perennial problem.

Keywords: velocity anisotropy, geomechanical properties, geomechanical characterization, minimum horizontal stress, maximum horizontal stress.
\end{abstract}

DOI: $10.7176 / \mathrm{JEES} / 9-5-04$

Publication date:May $31^{\text {st }} 2019$

\section{Introduction}

Knowledge of rock mechanical properties and wellbore stress regime is important for the economic development of hydrocarbon resources. In addition to identification of target zones for optimizing hydraulic fracture stimulation and well completion, characterization of geomechanical properties also aid safe and cost effective drilling of petroleum wells. A number of wellbores have been lost in the past due to inability to overcome the technical challenges of safe and cost effective drilling, identification of target zones for well placement and borehole instability. Shear failure in the wall of the wellbore causes cavings, slackoffs, overpulls and even stuck pipe events arising from mis-calculations of the mud weight used for the drilling (Konstantinovkaya et al., 2016). Breakouts occur in intervals of unstable weak shales The combination of these factors cause cost and safety issues during drilling and well placement. Geomechanical characterization provides a measure of assessing the subsurface heterogeneity-related variability of well completion quality across an asset, and the evaluation, modeling and monitoring of geomechanical data is key to wellbore stability assessment to assist in identification of areas vulnerable to fracturing/faulting during developmental drilling and completion designs to mitigate risks attributable to compactions, prediction of stress sweet spots for side-tracks or re-drill campaigns to reach targets (Xiao et al., 2016) and safe and cost effective execution of the field life. Opportunity cost and the additional cost due to well side-tracks or re-drill campaigns to reach target zones can be very impactful on the business (Mody and Wang, 2008).

Rock's mechanical properties are determined directly from measurements on core samples or inferred from rock physics modeling of geophysical well logs. Measurements on core samples are thought to be more accurate, but are limited to cost and sparsity of measurement points, in comparison to well log-derived geomechanical 
properties which can be available throughout a reservoir and the bounding formations. Consequently, well logs are an ideal source of geomechanical data (Edlmann et al., 1998). Slota-Valim (2013) opines that some geomechanical properties can also be determined directly from seismic data or a combination of seismic and well logs. Well logs are more readily available for offset wells within a field, in contrast to core samples which can become available for analysis only after the well has been drilled or when it is being drilled. Geomechanical properties determined from well logs are dynamic mechanical properties. They are valid for small stress and strains typically associated with seismic or sonic waves. They need to be transformed into static values which valid for the analysis of the geomechanical behaviour of rocks under larger stress and strains. Empirical models are used to convert the dynamic properties to static rock mechanical properties which are then related to rock strength (Archer and Rasouli, 2012; Najibi et al., 2015; Xu et al., 2016) and other static rock mechanical properties. Rock strength is a measure of the ability of a rock to withstand deformation up to catashtrophic failure. In this context, loading is the application of a force to the rock material. The empirical models are premised on the belief that some of the rock properties which control the dynamic properties also influence the static properties (Steiner, 1996).

Due to the sand-shale stratification in sedimentary basins, and preferential alignment of clay minerals in shales during sedimentation, layered sediments are intrinsically anisotropic to elastic wave propagation. Other factors which cause anisotropy are distribution of porosity and organic matter, and bedding parallel microcracks (Vernik, 1994). More specifically, subsurface formations at depths are subjected to in situ anisotropic stresses which act in the vertical and horizontal directions, and are due to the weight of the overburden and confined lateral strain arising from the applied pressure, respectively. These stresses are in a state of equilibrium at in situ conditions, but the action of drilling causes their re-distribution along the wall of the wellbore to re-establish equilibrium (Bassey et al., 2011). This process may cause hole instability and rock failure especially in areas with the highest stress concentration, unless a support pressure, which comes from the mud weight, is introduced to maintain equilibrium. Inclusion of anisotropy in geomechanical characterization can significantly impact the response of subsurface rocks to changes in stress and strain, and consequently influence the understanding of the wellbore stability. Shales are known to account for about $90 \%$ of wellbore instability in the Niger Delta (Dosunmu, 2014), probably due to the intrinsic anisotropy in shale formations. However, due to the complexity in inclusion of anisotropy in the mechanical behavior of rocks, isotropic stratifications have been assumed for subsurface layers thereby neglecting anisotropy in most field explorations (Higgins et al., 2008; Zamiran et al., 2018). Isotropic assumption makes well log-based characterization of the dynamic mechanical properties of the rocks to be relatively easy and straightforward, but results in imprecise solutions of stress analyses (Higgins et al., 2008; Thiercelin and Plumb, 1994). The ability to characterize the anisotropic mechanical behavior of rocks using geophysical well logs allows for the characterization of the in situ state of stress, including mapping of lithologic changes between wells and hydraulic fracture modeling, all of which influence wellbore stability analyses.

A number of geomechanical reservoir evaluations carried out in the Niger Delta in the past have assumed isotropy in deriving rock's mechanical properties from well logs, for example, Harry et al., 2018, Abijah and Tse, 2016, Lawson-Jack et al., 2018 and Davies et al., 2019. However, due to the presence of clay minerals in shales and the potential for different fracture orientations, it is important to consider anisotropy in the characterization of mechanical properties of rocks to aid exploration and economic development of proven reservoirs in the Niger Delta. This is more so due to the evidently sequential sand-shale layering and the presence of shale streaks in most of the reservoirs in the Niger Delta. Volume fraction sets computed from GR logs in the study area (Figure 1) typically reveal thick layers of shale bounding the reservoirs which themselves, are saddled with intra heterolithic shale members. Therefore, in this study, we carried out anisotropic characterization of mechanical rock properties with the aim of precisely determining suitable parameters to aid design of stable wells and for cost effective and successful drilling. Our focus in this study is the determination of the anisotropic Young's modulus and Poisson's ratio which constitute the main parameters used to explain elastic deformation (Iqbal et al., 2017), and their transformation to formation strength and stress. Poisson's ratio and Young's modulus are functions of the bulk and shear moduli, which in turn, are functions of the compressional and shear velocity, and density. The Young's modulus is a stress-strain relationship that describes the stiffness of a material, while the Poisson's ratio is the ratio of the lateral expansion of a material to the axial shortening when the material is subjected to axial loading. 

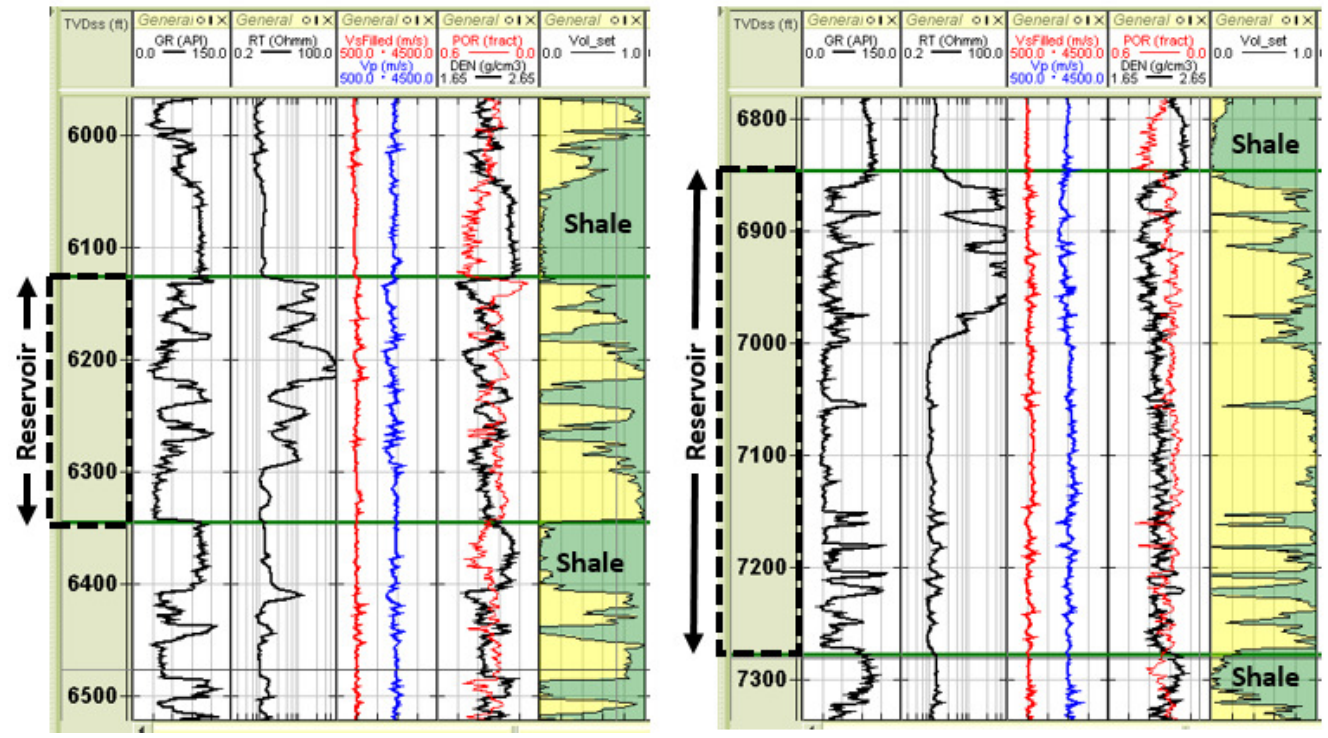

Figure 1: Typical reservoirs in the study area

\section{Location and Geological Setting}

The Sojuko field area is located in the shallow offshore depobelt in eastern part of the Niger Delta (Figure 2). Reservoir sands in the area are in continual development but at present, are of the Late Miocene age. The literature is awash of scholarly documentations on the petroleum system, structural styles and stratigraphy of the Niger Delta (Short \& Stauble, 1967; Burke, 1972; Avbovbo, 1978; Evamy et al., 1978; Ejedawe, 1981; Whiteman, 1982; Doust \& Omatsola, 1990; Reijers et al., 1997; Tuttle et al., 1999).

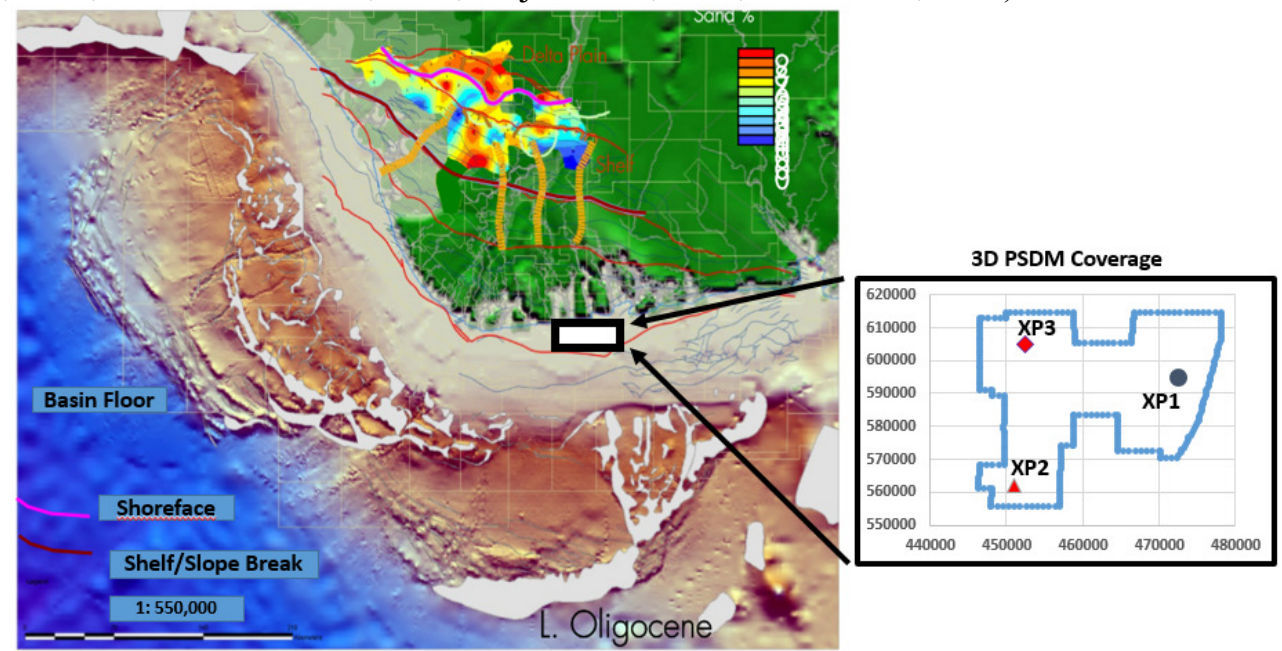

Figure 2: Map of the Niger Delta showing the study area and the exploratory well locations.

\section{Materials and Methods}

\subsection{Materials}

Only well XP2, of the three (3) exploratory wells in the field, have the requisite data for this study, which include compressional and shear sonic log, bulk density and GR logs, including well deviation data. The remaining two (2) have no shear information. 3D pore pressure data was also provided from which pore pressure profile was to be extracted along the well trajectory for the study.

\subsection{Stiffness Constant Modeling}

The Transverse isotropy with vertical axis of symmetry, known as vertical transverse isotropy (VTI), is the most common type of anisotropy in sedimentary rocks (Jones et al., 2003). Characterizing the dynamic mechanical properties of rocks in VTI media requires the determination of five independent parameters, which can be stiffness parameters, elastic moduli or the Thomsen's anisotropy parameters.

Using the Voigt's two-index notation, Hooke's law can be expressed as:

$$
\sigma_{i}=C_{i j} \varepsilon_{j}
$$


where $C_{i j}$ is elastic stiffness tensor which relates the stress $\left(\sigma_{i}\right)$ to strain $\left(\varepsilon_{j}\right)$. Five independent parameters are required to define the elastic stiffness tensor in a vertically transverse isotropic medium. These parameters are associated with seismic velocities measured parallel and normal bedding, and at $45^{\circ}$, and are defined by:

$$
\begin{aligned}
C_{11}= & V_{P}\left(90^{0}\right)^{2} \rho \\
C_{33}= & V_{P}\left(0^{0}\right)^{2} \rho \\
C_{44}= & V_{S}\left(0^{0}\right)^{2} \rho \\
C_{66}= & V_{S}\left(90^{0}\right)^{2} \rho \\
C_{12}= & V_{p}\left(90^{0}\right)^{2} \rho-2 V_{S}\left(90^{0}\right)^{2} \rho \\
& C_{13}=-C_{44}+\sqrt{ }\left[4 \rho V_{P}\left(45^{0}\right)^{4}-2 \rho V_{P}\left(45^{0}\right)^{2}\left(C_{11}+C_{33}+2 C_{44}\right)+\left(C_{11}+C_{44}\right)\left(C_{33}+C_{44}\right)\right](7)
\end{aligned}
$$

where $V_{P}\left(0^{0}\right), V_{S}\left(0^{0}\right)$ are velocities measured in the vertical direction, equivalent to compressional and shear sonic velocities from the well, and $V_{P}\left(90^{\circ}\right), V_{S}\left(90^{\circ}\right)$ are compressional and shear velocities measured in the horizontal directions.

The stress-strain relationship for rock deformation in the vertical and horizontal directions is given by the dynamic Young's modulus, $E\left(0^{\circ}, d y n\right)$ and $E\left(90^{\circ}, d y n\right)$, respectively. These are given as follows (Higgins et al., 2008):

$$
\begin{aligned}
& E\left(0^{0}, \text { dyn }\right)=C *\left(C_{11}+C_{12}\right)^{-1} \\
& E\left(90^{0}, \text { dyn }\right)=\left[C *\left(C_{11}-C_{12}\right)\right] *\left[C_{11} C_{33}-C_{13}{ }^{2}\right]^{-1}
\end{aligned}
$$

where $C=C_{33}\left(C_{11}+C_{12}\right)-2 C_{13}^{2}$

The dynamic Poisson's ratio is the ratio of transverse strain to longitudinal strain, but in a VTI medium it is dependent on the orientation of the axial and radial strains relative to the vertical. The vertical and horizontal dynamic Poisson's ratio are given as follows (Higgins et al., 2008):

$$
\begin{aligned}
& \vartheta\left(0^{0}\right)=C_{13} *\left[C_{11}+C_{12}\right]^{-1} \\
& \vartheta\left(90^{0}\right)=\left(C_{12} C_{33}-C_{13}{ }^{2}\right) *\left[C_{11} C_{33}-C_{13}{ }^{2}\right]^{-1}
\end{aligned}
$$

A major difficulty in the determination of the above anisotropic mechanical properties is the derivation of the stiffness parameters $C_{13}, C_{11}$ and $C_{66}$ since the horizontal compressional and shear velocities $\left(V_{P}\left(90^{0}\right), V_{S}\left(90^{0}\right)\right.$ are not usually accessible (Jones, 2015). Assuming a weak transversely isotropic medium, Thomsen (1986) defines the parameters $\varepsilon$ and $\gamma$ to describe the $\mathrm{P}$-wave and S-wave anisotropy respectively, and the parameter $\delta$ is near vertical anisotropy describing seismic-to-well mistie. These are defined as:

$$
\begin{aligned}
& \varepsilon=\left(C_{11}-C_{33}\right) *\left(2 C_{33}\right)^{-1} \\
& \gamma=\left(C_{66}-C_{44}\right) *\left(2 C_{44}\right)^{-1} \\
& \delta=\left[\left(C_{13}-C_{44}\right)^{2}-\left(C_{33}-C_{44}\right)^{2}\right] * 2 C_{33}\left(C_{33}-C_{44}\right)^{-1}
\end{aligned}
$$

Re-arranging Eq. 14 gives:

$$
C_{13}=\rho\left[\left(V_{P}^{2}(0)-V_{S}^{2}(0)\right) *\left(V_{P}^{2}(0) *(1+2 \delta)-V_{S}^{2}(0)\right)\right]^{0.5}-\rho V_{S}(0)^{2}
$$

We extracted seismic interval velocity function along well XP2 trajectory from the 3D PSDM interval velocity volume covering the field. Following Ogagarue and Ebeniro (2018), we derived the delta anisotropy parameter, $\delta$, by comparing the extracted seismic velocity function and checkshot-derived interval velocity at the well location using Eq. 16. The computed delta anisotropy was then used in Eq. (15) to derive $C_{13}$.

$\delta=\left(V_{\text {seismic }}-V_{\text {well }}\right) *\left(V_{\text {well }}\right)^{-1}$

Jones et al. $(2002 ; 2003)$ and Jones $(2015)$ report that the epsilon anisotropy typically varies between $1.5 \delta$ and $2.0 \delta$ in sedimentary basins. Fruehn et al. (2007), using gridded tomography, derived delta and epsilon anisotropy of $10 \%$ and $20 \%$, respectively, for the overpressured shale unit of offshore Niger Delta. Consequently for this study, we derived the Thomsen's epsilon anisotropy using Eq. 17 and subsequently derived the stiffness parameter, $C_{11}$ using Eq. (12).

$\varepsilon=2.0 * \delta$

Wang (2002) relates S-wave anisotropy $(\gamma)$ to the P-wave anisotropy (Eq. 18), and utilizing this relation, we derived the remaining unknown stiffness parameter, $C_{66}$, using Eg. (13).

$\gamma=-0.01049+0.9560 \varepsilon$

With the respective stiffness parameters derived, we finally determined the anisotropic mechanical rock properties which are the dynamic vertical and horizontal Young's moduli $E(0)^{0}, E(90)^{0}$ and the dynamic vertical and horizontal Poisson's ratio $\vartheta(0)^{0}, \vartheta(90)^{0}$ using Eq. $(8-11)$. The Wang's equation (Wang and Nur, 2000 ) is widely used in the industry for transforming dynamic Young's modulus to static Young's modulus in soft rocks (Zamiran et al., 2018; Honour et. al., 2019). We used this equation (Eq. 19) to obtain static values from the Young's moduli.

$E_{\text {stat }}=0.4145 E_{\text {dyn }}-1.0593$

A number of laboratory evaluations carried out in the literature have revealed that there is no obvious relationship between the dynamic and static Poisson's ratio and as such, the dynamic Poisson's ratio has largely been assumed to be equivalent to the static Poisson's ratio (Yale and Jamieson, 1994; Wang and Nur, 2000; Fei 
et al., 2016; Zamiran et al., 2018) in geomechanical characterization. Consequently, we have assumed in this study, that:

$\vartheta_{\text {stat }}=\vartheta_{\text {dyn }}$

\subsection{Rock Strength Computations}

Rock strength indicators are important in prediction of the response of formation rocks to the large values of stress encountered during drilling and exploitation. The anisotropic geomechanical parameters derived in the above section were utilized in computing two important rock strength indicators which include the initial shear strength (ISS) and unconfined compressive strength (UCS).

Initial Shear Strength (ISS)

Using the results of Deere and Miller (1966), Coates and Denoo (1981) derived the now generally used empirical relation to relate the dynamic Young's modulus to rock strength. The Coates-Denoo relation, given in Eq. (21), was used in the estimation of the initial shear strength in this study.

$I S S=\frac{0.026 E_{d y n}}{C_{b} \times 10^{6}} *\left\{0.008 V_{s h l}+0.0045\left(1-V_{s h l}\right)\right\}$

where,

ISS $\quad=\quad$ initial shear strength

$C_{b} \quad=\quad$ bulk compressibility in $\mathrm{psi}^{-1}$

$V_{\text {shl }}=\quad$ volume of shale, derived from lithologic volume sets created from GR log

$E_{d y n}=$ dynamic Young's modulus in psi

Unconfined Compressive Strength (UCS)

McNally (1987), emphasized in Chang et al. (2006), derived unconfined compressive strength from well log compressional sonic velocity for fine grained, consolidated and unconsolidated sandstones with all ranges of porosities for the Bowen Basin, Australia. The relation, given in Eq. (22), has been implemented by a number of authors for the computation of rock's unconfined compressive strength in the Niger Delta (Abijah and Tse, 2016; Lawson-Jack et al, 2019).

$U C S=1200 \exp ^{-0.036(\Delta t)}$

Horsrud (2001) derived unconfined compressive strength using compressional sonic log data from mostly Tertiary shales with high porosity in the North Sea. Bassey et al. (2011) utilized the relation (Eq. 23) develop mud weight prediction window for Aret well 1, Niger Delta.

$U C S=0.77\left(\frac{304.8}{\Delta t}\right)^{2.93}$

where $\Delta t$ is sonic interval transit time in $\mu s e c / f t$ and UCS is in mega Pascal (MPa).

The focus in this study is to derive profiles of rock mechanical properties along hole to aid decision making. Bearing in mind the thick shale layers bounding reservoirs in the study area and the fact that the reservoirs are themselves shaley, we combined Eqs. (22) and (23) to obtain reasonable estimate of the unconfined compressive strength using shale percentage as the delimiter. Consequently, we utilized Eq. (24) to estimate the unconfined compressive strength in the respective lithologies to obtain an average unconfined compressive strength along hole for this study.

IF $V_{\text {shl }} \leq 0.65$ THEN X ELSE Y END

where $X=1200 \exp ^{-0.036(\Delta t)}$ and $Y=0.77\left(\frac{304.8}{\Delta t}\right)^{2.93}$.

Angle of Internal Friction $(\varphi)$

Angle of internal friction, in degree, for sand lithology was computed using the Weingarten and Perkins (1995) relation (Eq. 25) while the Lal's (1999) empirical relation (Eq. 26) was used to compute that for the shale sections, respectively.

$\varphi=57.8-105(\varnothing)$

$\varphi=\operatorname{Sin}^{-1}\left(\frac{V_{P}-1000}{V_{P}+1000}\right)$

where $\emptyset$ is porosity in volume fraction.

\subsection{Computation of Horizontal Stresses}

One major use of geomechanical properties is the estimation of the minimum stress profile which is used as input in hydraulic fracture simulation. Amadei et al. (1987) proposed a model which relates the minimum horizontal stress to the vertical effective stress as a function of the anisotropic Poisson's ratio and Young's modulus, assuming the horizontal stress is gravity induced. This model $(\mathrm{Eq}, 27)$ was used in this study to determine the anisotropic minimum horizontal stress. 
Shmin $=\left(\frac{E_{H}}{E_{V}}\right)\left(\frac{P R_{v}}{1-P R_{H}}\right) \sigma_{v}+P_{P}$

where $E_{V}, E_{H}, P R_{V}$, and $P R_{H}$ are the vertical and horizontal Young's modulus and Poisson's ratio, respectively, and $\sigma_{V}$ and $P_{P}$ are the vertical effective stress and pore fluid pressure.

The vertical effective stress is the pressure exerted by the rock mass alone, excluding the contribution from pore fluids. It is obtained by subtracting pore fluid pressure at a given depth from the overburden pressure, defined as the weight of overburden above that depth in accordance with the Terzaghi's principle. In this study, we computed the vertical effective stress from an overburden pressure derived from integration of the bulk density logs from the three exploratory wells, and pore pressure profile extracted along XP2 well trajectory from a 3D pore pressure volume supplied for this research (Figure 3).

The maximum horizontal stress is known to be very difficult to estimate. In some cases, an arbitrary factor is assumed and the minimum horizontal stress is multiplied by the factor to obtain a value for the maximum horizontal stress. In a recent study, using stress polygon analysis at varying depths, Ramjohn et al (2018) constrained accurate maximum horizontal stress profiles from minimum horizontal stress derived from leak-off tests, for some wells in a sedimentary basin. The horizontal stress profiles were digitized and cross-plotted, and the best-fit regression arising therefrom (Figure 4) was used to estimate reasonable estimate of the maximum horizontal stress profile for this study.

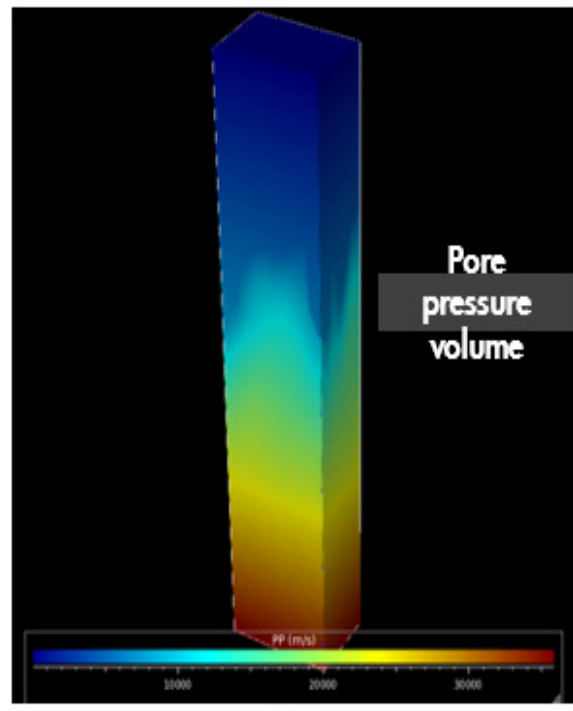

(a)

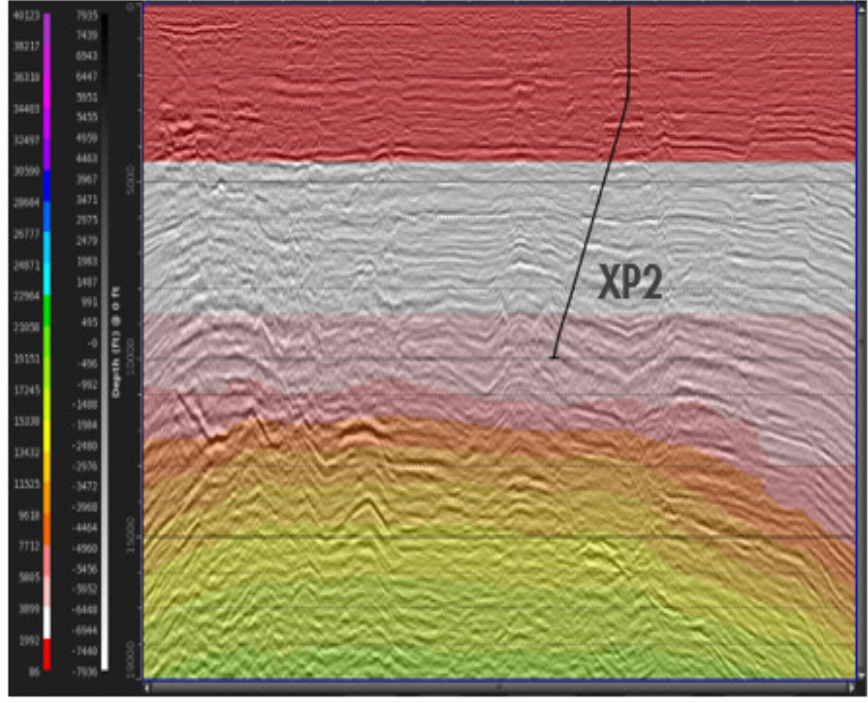

(b)

Figure 3: Sojuko field 3D pore pressure: (a) Pressure cube (b) pore pressure along arbitrary seismic line across well XP2.

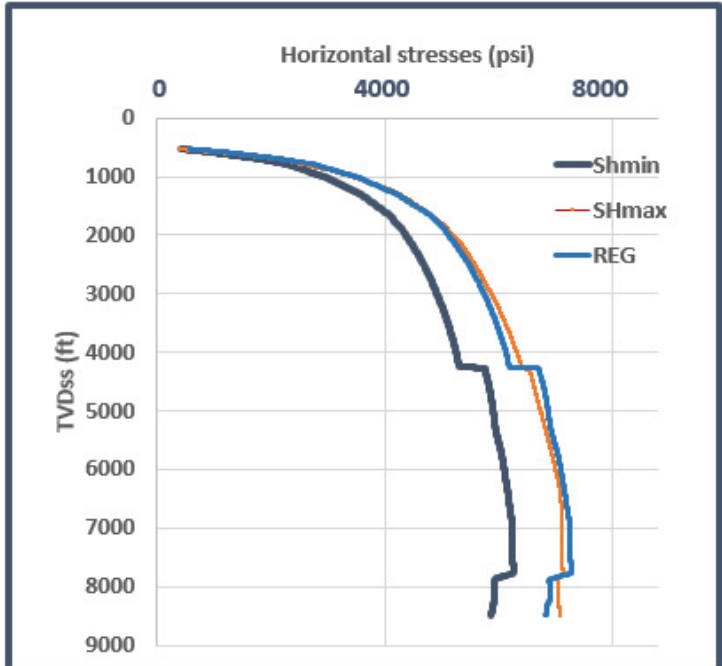

(a)

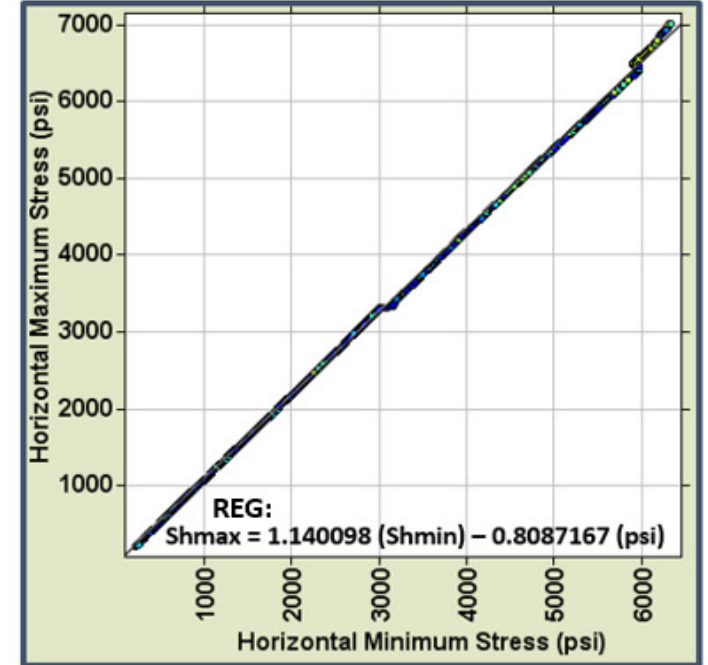

(b)

Figure 4: Maximum stress determination (a) minimum and constrained maximum horizontal stress (Ramjohn et al., 2018) and (b) horizontal stress regression analysis 


\subsection{Determination of Drilling Mudweight and Borehole Stability Analysis}

The mudweight, determined by the pressure in the drilling mud, has both safety and cost implications in exploratory and developmental drilling of petroleum wells, and accurate determination of the mudweight is critical to the success of well drilling. There is usually a drilling mudweight window while drilling such that if the mudweight is lower than the lower limit of the window, shear failure occurs and there is breakout or collapse of the wellbore wall with subsequent influx of formation fluids into the wellbore. On the other hand, if the mudweight is higher that the upper limit of the mudweight window, tensile failure occurs, causing fracturing of the formation and subsequent leak-off of drilling mud into the formation. Safe and cost-effective drilling ensures that neither of these conditions occurs during drilling and as such, the optimum drilling mudweight is such that has been determined to keep the well safe by preventing both shear and tensile failure, and is ideally a value inbetween the lower and upper limits. In some cases, a given amount of pressure $\Delta P$, is assumed and added to the formation pore pressure to provide a safe drilling overbalance such that the minimum mudweight, $M W_{L L}$ must be equal or greater than the sum of the pore pressure plus the overbalance.

In this study, the minimum drilling mudweight, below which shear failure would occur, has been determined by the application of the Mohr-Coulomb Failure Criteria, following Pandey (2017) using Eq. (28).

$$
M W_{L L}=\left[\frac{1}{K_{P}+1}\right] *\left\{\frac{3 * S H_{\max }-S h_{\min }-U C S+\left(K_{P}-1\right) * P_{P}}{(D * 1.422) / 8.33}\right\}
$$

where $K_{P}$ is passive Mohr-Coulomb coefficient which is related to the Angle of Internal Friction $(\varphi)$ by:

$K_{P}=\frac{1+\operatorname{Sin}(\varphi)}{1-\operatorname{Sin}(\varphi)}$

The upper drilling mudweight is not expected to be higher than the minimum horizontal stress. Therefore, the safe mudweight drilling window in this study has been determined using the relation:

$\left(\frac{M W_{L L}}{\text { TVDss }(f t)}\right) \geq M W_{\text {optimum }} \leq\left(\frac{S h_{\min }}{T V D s s(f t)}\right)$

The depth, D, in Eq. (28) is in meters, and the mudweight is estimated in units of pounds per gram (ppg).

\section{Results and Discussion}

Analysis of interval velocity from sonic, seismic and checkshot data at the well location shows that the effect of anisotropy is pronounced in the data from about 6,800 ft TVDss (Figure 5). From the figure, it is evident that for the anisotropic interval, the computed stiffness constants hold the relation $C_{11}>C_{33}>C_{12}>C_{13}>C_{66}>$ $C_{44}$. This agrees well with the result of Wang (2002). The stiffness constants generally increase with depth in the anisotropic interval. Table 1 shows typical stiffness constants computed for different lithologies and reservoir tops in the anisotropic interval in well XP2.

Table 1. Typical stiffness constants at different rock types and well markers in the anisotropic interval in well XP2

\begin{tabular}{lccccccc}
\hline $\begin{array}{l}\text { TVDss } \\
(\mathrm{ft})\end{array}$ & $\begin{array}{c}\text { Marker/ } \\
\text { Rock type }\end{array}$ & $\begin{array}{c}\text { C11 } \\
(\mathrm{psi})\end{array}$ & $\begin{array}{c}\text { C33 } \\
(\mathrm{psi})\end{array}$ & $\begin{array}{c}\mathrm{C} 12 \\
(\mathrm{psi})\end{array}$ & $\begin{array}{c}\text { C13 } \\
(\mathrm{psi})\end{array}$ & $\begin{array}{c}\text { C66 } \\
(\mathrm{psi})\end{array}$ & $\begin{array}{c}\text { C44 } \\
(\mathrm{psi})\end{array}$ \\
\hline 6846 & RT_1 & $2.24 \mathrm{E}+07$ & $2.21 \mathrm{E}+07$ & $1.28 \mathrm{E}+07$ & $1.25 \mathrm{E}+07$ & 4792545.61 & 4821970.75 \\
6981.5 & Sand & $1.70 \mathrm{E}+07$ & $1.64 \mathrm{E}+07$ & 8838646.24 & 8502046.66 & 4069649.79 & 4014676.77 \\
7089.5 & Sand & $2.26 \mathrm{E}+07$ & $2.13 \mathrm{E}+07$ & $1.17 \mathrm{E}+07$ & $1.11 \mathrm{E}+07$ & 5447730.03 & 5259281.17 \\
7307.5 & RT_2 & $2.45 \mathrm{E}+07$ & $2.18 \mathrm{E}+07$ & $1.33 \mathrm{E}+07$ & $1.23 \mathrm{E}+07$ & 5568395.08 & 5076725.21 \\
7365 & Sand & $2.25 \mathrm{E}+07$ & $1.97 \mathrm{E}+07$ & $1.34 \mathrm{E}+07$ & $1.23 \mathrm{E}+07$ & 4520862.5 & 4058018.39 \\
7483 & Sand & $2.26 \mathrm{E}+07$ & $1.90 \mathrm{E}+07$ & $1.20 \mathrm{E}+07$ & $1.07 \mathrm{E}+07$ & 5309295.85 & 4587695.23 \\
7587 & RT_3 & $2.83 \mathrm{E}+07$ & $2.31 \mathrm{E}+07$ & $1.70 \mathrm{E}+07$ & $1.49 \mathrm{E}+07$ & 5688310.85 & 4752085.02 \\
7759.5 & RT_4 & $2.49 \mathrm{E}+07$ & $1.92 \mathrm{E}+07$ & $1.31 \mathrm{E}+07$ & $1.12 \mathrm{E}+07$ & 5883844.67 & 4677783.47 \\
7935 & Shale & $2.36 \mathrm{E}+07$ & $1.77 \mathrm{E}+07$ & $1.32 \mathrm{E}+07$ & $1.11 \mathrm{E}+07$ & 5227683.22 & 4012799.16 \\
8043 & Shale & $2.91 \mathrm{E}+07$ & $2.13 \mathrm{E}+07$ & $1.37 \mathrm{E}+07$ & $1.16 \mathrm{E}+07$ & 7692886.07 & 5781312.74 \\
8102 & Shale & $2.63 \mathrm{E}+07$ & $1.90 \mathrm{E}+07$ & $1.41 \mathrm{E}+07$ & $1.17 \mathrm{E}+07$ & 6111625.3 & 4540424.43 \\
8265 & RT_5 & $2.95 \mathrm{E}+07$ & $2.07 \mathrm{E}+07$ & $1.50 \mathrm{E}+07$ & $1.23 \mathrm{E}+07$ & 7281247.31 & 5249498.78 \\
8357.5 & Sand & $3.07 \mathrm{E}+07$ & $2.12 \mathrm{E}+07$ & $1.51 \mathrm{E}+07$ & $1.24 \mathrm{E}+07$ & 7785309.36 & 5528648.22 \\
8506 & RT_6 & $3.05 \mathrm{E}+07$ & $2.09 \mathrm{E}+07$ & $1.51 \mathrm{E}+07$ & $1.23 \mathrm{E}+07$ & 7674525.11 & 5424645.21 \\
8583.5 & Sand & $3.56 \mathrm{E}+07$ & $2.44 \mathrm{E}+07$ & $1.52 \mathrm{E}+07$ & $1.26 \mathrm{E}+07$ & $1.02 \mathrm{E}+07$ & 7184681.88 \\
8800 & Shale & $3.68 \mathrm{E}+07$ & $2.52 \mathrm{E}+07$ & $1.77 \mathrm{E}+07$ & $1.45 \mathrm{E}+07$ & 9574004.19 & 6750273.75 \\
8888.5 & RT_7 & $4.53 \mathrm{E}+07$ & $3.11 \mathrm{E}+07$ & $1.65 \mathrm{E}+07$ & $1.40 \mathrm{E}+07$ & $1.44 \mathrm{E}+07$ & $1.02 \mathrm{E}+07$ \\
\hline
\end{tabular}




\begin{tabular}{lccccccc}
\hline $\begin{array}{l}\text { TVDss } \\
\text { (ft) }\end{array}$ & $\begin{array}{c}\text { Marker/ } \\
\text { Rock type }\end{array}$ & $\begin{array}{c}\text { C11 } \\
(\mathrm{psi})\end{array}$ & $\begin{array}{c}\text { C33 } \\
(\mathrm{psi})\end{array}$ & $\begin{array}{c}\mathrm{C} 12 \\
(\mathrm{psi})\end{array}$ & $\begin{array}{c}\mathrm{C} 13 \\
(\mathrm{psi})\end{array}$ & $\begin{array}{c}\text { C66 } \\
(\mathrm{psi})\end{array}$ & $\begin{array}{c}\text { C44 } \\
(\mathrm{psi})\end{array}$ \\
\hline 8996.5 & Sand & $3.28 \mathrm{E}+07$ & $2.25 \mathrm{E}+07$ & $1.35 \mathrm{E}+07$ & $1.13 \mathrm{E}+07$ & 9644480.89 & 6816743.93 \\
9114 & Sand & $3.31 \mathrm{E}+07$ & $2.27 \mathrm{E}+07$ & $1.43 \mathrm{E}+07$ & $1.19 \mathrm{E}+07$ & 9391620.57 & 6636179.54 \\
9176.5 & RT_8 & $4.44 \mathrm{E}+07$ & $3.05 \mathrm{E}+07$ & $1.98 \mathrm{E}+07$ & $1.63 \mathrm{E}+07$ & $1.23 \mathrm{E}+07$ & 8691036.78 \\
9254 & Sand & $3.93 \mathrm{E}+07$ & $2.70 \mathrm{E}+07$ & $1.58 \mathrm{E}+07$ & $1.32 \mathrm{E}+07$ & $1.17 \mathrm{E}+07$ & 8306077.95 \\
9361 & Shale & $3.57 \mathrm{E}+07$ & $2.47 \mathrm{E}+07$ & $1.70 \mathrm{E}+07$ & $1.39 \mathrm{E}+07$ & 9392646.88 & 6668397.35 \\
9410.5 & RT_9 & $4.99 \mathrm{E}+07$ & $3.44 \mathrm{E}+07$ & $2.17 \mathrm{E}+07$ & $1.80 \mathrm{E}+07$ & $1.41 \mathrm{E}+07$ & $1.00 \mathrm{E}+07$ \\
9438 & Shale & $3.95 \mathrm{E}+07$ & $2.72 \mathrm{E}+07$ & $1.56 \mathrm{E}+07$ & $1.31 \mathrm{E}+07$ & $1.19 \mathrm{E}+07$ & 8460406 \\
9635 & Sand & $3.35 \mathrm{E}+07$ & $2.32 \mathrm{E}+07$ & $1.39 \mathrm{E}+07$ & $1.17 \mathrm{E}+07$ & 9793468.99 & 6978975.34 \\
9645 & Sand & $3.20 \mathrm{E}+07$ & $2.22 \mathrm{E}+07$ & $1.15 \mathrm{E}+07$ & 9816628.8 & $1.03 \mathrm{E}+07$ & 7327096.29 \\
9841.5 & Shale & $3.47 \mathrm{E}+07$ & $2.41 \mathrm{E}+07$ & $1.64 \mathrm{E}+07$ & $1.35 \mathrm{E}+07$ & 9160746.04 & 6538703.24 \\
9915 & RT_10 & $4.30 \mathrm{E}+07$ & $3.00 \mathrm{E}+07$ & $1.35 \mathrm{E}+07$ & $1.19 \mathrm{E}+07$ & $1.48 \mathrm{E}+07$ & $1.06 \mathrm{E}+07$ \\
\hline
\end{tabular}

Symbols: True vertical depth sub-sea, stiffness constants C11, C33, C12, C13, C66 and C44

The focus of the anisotropic analysis is to accurately model the two important rock mechanical properties, the Young's modulus and Poisson's ratio, by consideration of vertical transverse isotropy in the modeling. The workflow adopted in this study enabled the determination of these properties in the vertical and horizontal directions thereby removing the assumption of isotropy in the geomechanical modeling. The essence is to accurately estimate the two principal horizontal stresses and other parameters for the accurate prediction of the drilling mudweight and analysis of borehole stability. Figure 6 shows the modeled compressional and shear sonic interval velocities, and the Young's modulus and Poisson's ratio in the vertical (slow) and horizontal (fast) directions. As expected, the modeled properties are approximate in the isotropic interval of the well, but different in the anisotropic interval where they are generally higher in the horizontal than the vertical direction. The horizontal compressional interval velocity is 0.05 to $17.2 \%$ higher than the vertical compressional velocity in the anisotropic interval, while the horizontal shear interval velocity increased from 0.02 to $16.7 \%$ relative to the vertical shear interval velocity.

The dynamic Young's modulus computed for the dataset is generally about $60 \%$ higher than the static value; the static Young's modulus in the symmetry plane is about $0.06 \%$ at the onset of anisotropy to $32.9 \%$ higher than that along the symmetry axis within the anisotropic interval. On the other hand, the horizontal Poisson's ratio is on the average $15.7 \%$ higher than the vertical Poisson's ratio in the anisotropic interval. Comparatively, the Young's modulus appears to be more sensitive to the VTI anisotropy than the Poisson's ratio. Table 2 shows the anisotropic velocities and the geomechanical properties at key reservoir tops within the anisotropic interval.

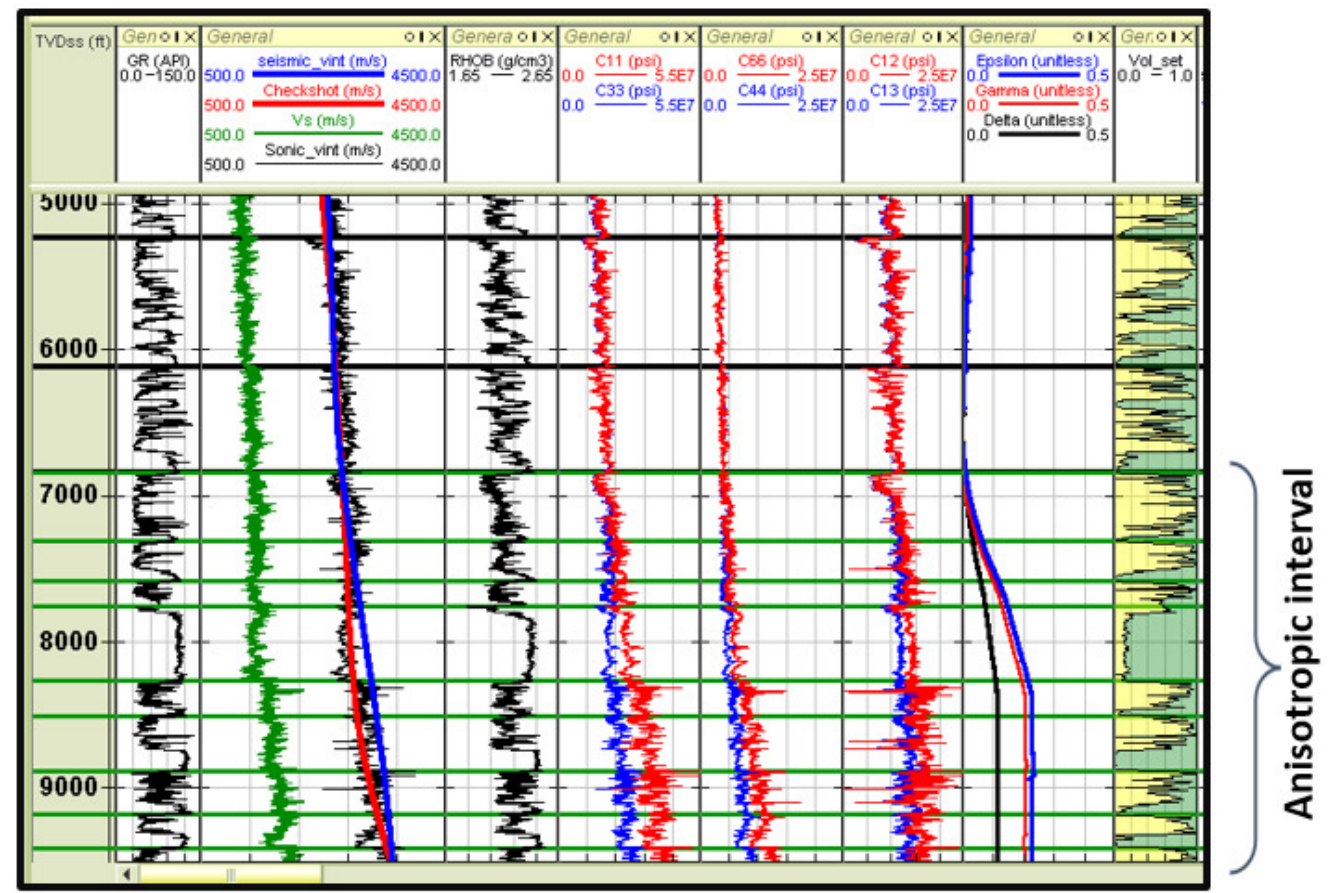


Figure 5: Rock elastic properties and computed stiffness constants for XP2 well with well markers. Track 1: GR; Track 2: Interval velocity from shear sonic (Green) and compressional sonic (Black), Seismic interval velocity (Blue) and checkshot (Red); Track 3: RHOB; Track 4: C11(Red). C33 (Blue); Track 5: C66 *Red), C44 (Blue); Track 6: C12 (Red); C13 (Blue); Track 7: Delta anisotropy (Black), Epsilon (Blue) and Gamma anisotropy (Blue); Track 7: Lithologic volume set.

Table 2. Anisotropic elastic and geomechanical parameters at reservoir tops in the anisotropic interval.

\begin{tabular}{lllllllllll}
\hline $\begin{array}{l}\text { TVDss } \\
(\mathrm{ft})\end{array}$ & Top & $\begin{array}{l}\text { RHOB } \\
(\mathrm{g} / \mathrm{cm} 3)\end{array}$ & $\begin{array}{c}\mathrm{Vp}(0) \\
(\mathrm{m} / \mathrm{s})\end{array}$ & $\begin{array}{l}\mathrm{Vp}(90) \\
(\mathrm{m} / \mathrm{s})\end{array}$ & $\begin{array}{l}\mathrm{Vs}(0) \\
(\mathrm{m} / \mathrm{s})\end{array}$ & $\begin{array}{l}\mathrm{Vs}(90) \\
(\mathrm{m} / \mathrm{s})\end{array}$ & $\begin{array}{l}\text { E_stat(0) } \\
(\mathrm{psi})\end{array}$ & $\begin{array}{l}\text { E_stat }(90) \\
(\mathrm{psi})\end{array}$ & PR(0) & PR(90) \\
\hline 6846 & RT_1 & 2.4300 & 3014 & 3037 & 1409 & 1404 & 5312200 & 5306909 & 0.3551 & 0.3744 \\
7307.5 & RT_2 & 2.3004 & 3077 & 3261 & 1486 & 1556 & 5564007 & 6147208 & 0.3251 & 0.3649 \\
7587 & RT_3 & 2.3431 & 3139 & 3478 & 1424 & 1558 & 5379803 & 6422818 & 0.3277 & 0.3946 \\
7759.5 & RT_4 & 2.0598 & 3057 & 3474 & 1507 & 1690 & 5068266 & 6466088 & 0.2960 & 0.3571 \\
8265 & RT_5 & 2.4031 & 2935 & 3506 & 1478 & 1741 & 5611078 & 7970142 & 0.2757 & 0.3459 \\
8506 & RT_6 & 2.1250 & 3138 & 3787 & 1598 & 1900 & 5768276 & 8367829 & 0.2699 & 0.3394 \\
8888.5 & RT_7 & 2.3584 & 3629 & 4385 & 2076 & 2473 & 10079288 & 14916151 & 0.2270 & 0.2604 \\
9176.5 & RT_8 & 2.4364 & 3537 & 4269 & 1889 & 2247 & 9034203 & 13202372 & 0.2545 & 0.3097 \\
9410.5 & RT_9 & 2.3877 & 3796 & 4570 & 2048 & 2431 & 10359318 & 15083374 & 0.2513 & 0.3030 \\
9915 & RT_10 & 2.3662 & 3527 & 4229 & 2095 & 2476 & 10199508 & 14899322 & 0.2096 & 0.2304 \\
\hline
\end{tabular}

Symbols: True vertical depth sub-sea, bulk density, vertical and horizontal compressional sonic interval velocity, vertical and horizontal shear sonic interval velocity, vertical and horizontal Young's modulus, vertical and horizontal Poisson's ratio.

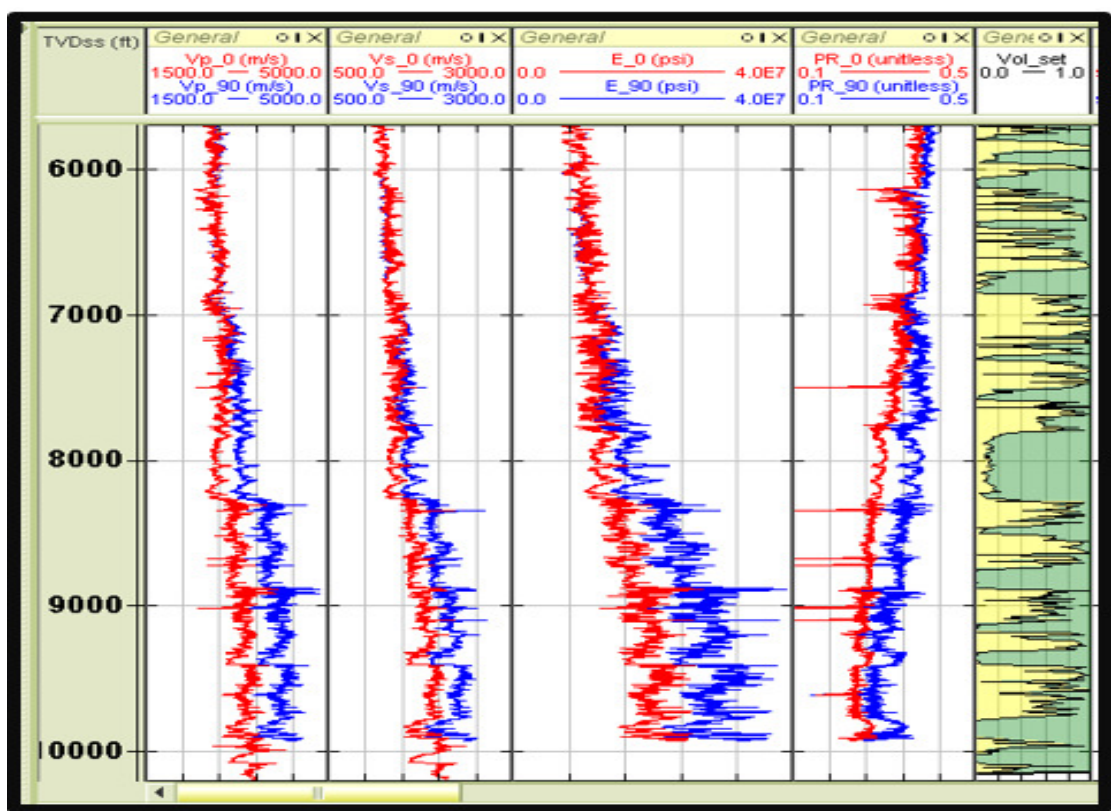

Figure 6: Anisotropic compressional and shear interval velocities, and Poisson's ratio and Young's modulus. The blue colour in each track indicates the horizontally-derived velocity and mechanical constants, and the red colour indicates the parameter derived in the vertical direction. (Track 1: Vp; Track 2: Vs; Track 3: Young's modulus; Track 4: Poisson's ratio; Track 5: Lithologic volume set)

From the study, the horizontal Young's modulus and Poisson's ratio can be related to the respective vertical components in the Niger Delta shallow offshore area (Figure 7) as follows:

$E_{90}($ stat $)=1.6713 * E_{0}($ stat $)-1971555$ (psi)

$P R_{90}=0.8603 * P R_{0}+0.079777$ 


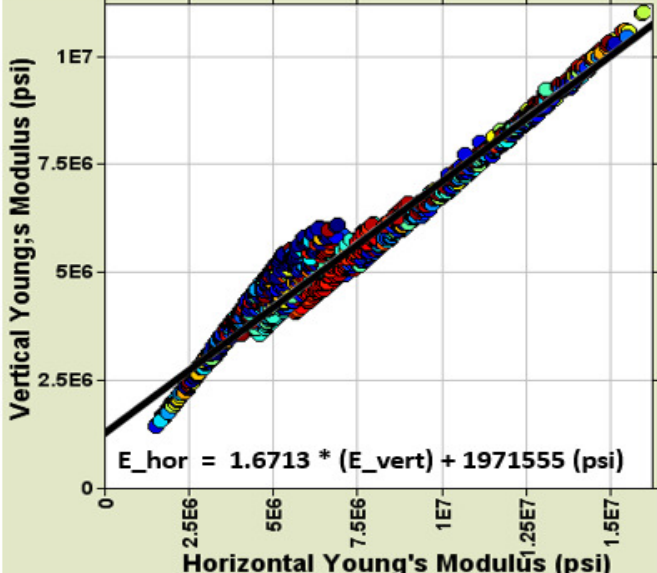

(a)

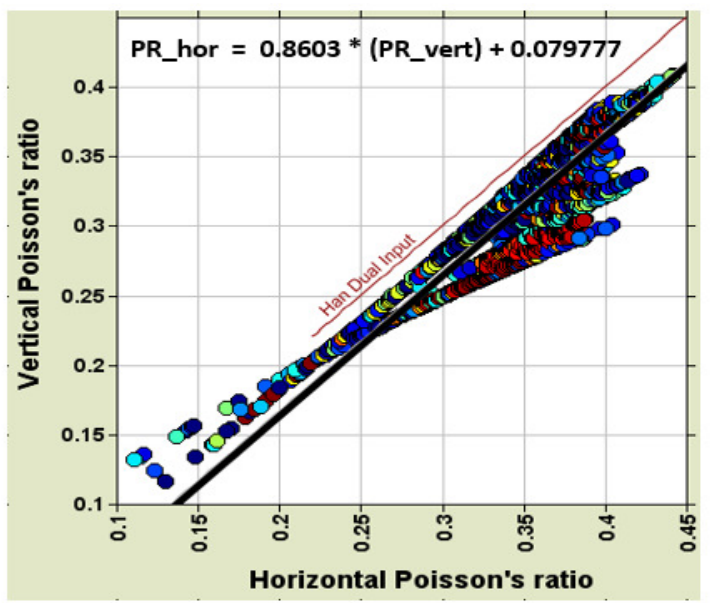

(b)

Figure 7: Relationship between anisotropic rock mechanical properties in the area

Figure 8 shows the rock strength and in situ stress profiles along the vertical well direction. The maximum Angle of Internal Friction (AIF) around the wellbore is approximately $50^{\circ}$, with an average of $26.2^{0}$ and $33^{\circ}$ for the isotropic and anisotropic interval, respectively, indicating an overall increase in the Internal Friction Angle with depth. The Unconfined Compressive Strength (UCS) around the wellbore varies from 512 psi to 8,837 psi, with an average of $2,728 \mathrm{psi}$. The UCS also generally increase with depth, with an average of 1,887 psi and 4,191 psi in the isotropic and anisotropic interval, respectively. The Angle of Internal Friction and Unconfined Compressive Strength in the area can be related (Figure 9 a) using the relation:

$U C S=335.4815 *(1.070999)^{A I F}$

The in situ minimum horizontal stress varies from about 727 psi to 7,500 psi, and it generally increases with depth with an average of 4,107 psi, and average gradient of $0.69 \mathrm{psi} / \mathrm{ft}$. The in situ maximum horizontal stress is $12.27 \%$ higher than the minimum horizontal stress at every depth along the well, indicating an average gradient of $0.713 \mathrm{psi} / \mathrm{ft}$. The in situ stress values obtained are reasonable, compared to the average pore pressure and vertical stress gradient of $0.435 \mathrm{psi} / \mathrm{ft}$ and $0.914 \mathrm{psi} / \mathrm{ft}$, respectively. This suggests that the relationship between the minimum and maximum horizontal stresses used for this study is reasonable and adequate for the study area. The minimum horizontal stress can be related to the Unconfined Compressive stress in the area (Figure 9 b) by: Shmin $=4.53668 *(U C S)^{0.860385}$

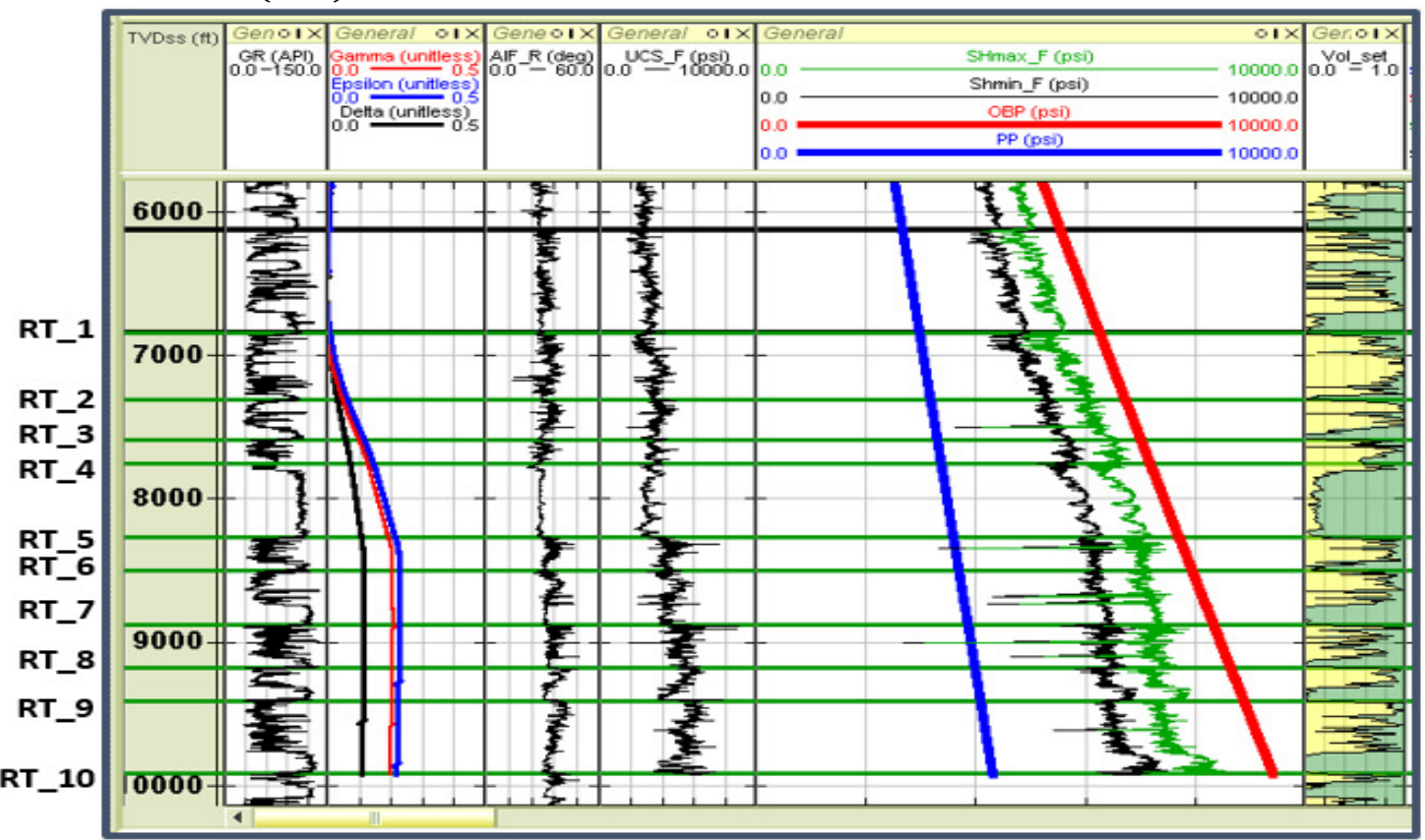

Figure 8: In situ stress and rock strength profiles: Track 1 (GR); Track 2 (Delta - Black; Gamma - Green \& Epsilon anisotropy - Blue); Track 3: Angle of Internal Friction; Track 4: Unconfined Compressive Strength; Track 5: (Pore pressure - Blue; Horizontal minimum stress - Black; Horizontal Maximum stress - Green \& Overburden stress - Red); Track 6: Lithologic volume set. 


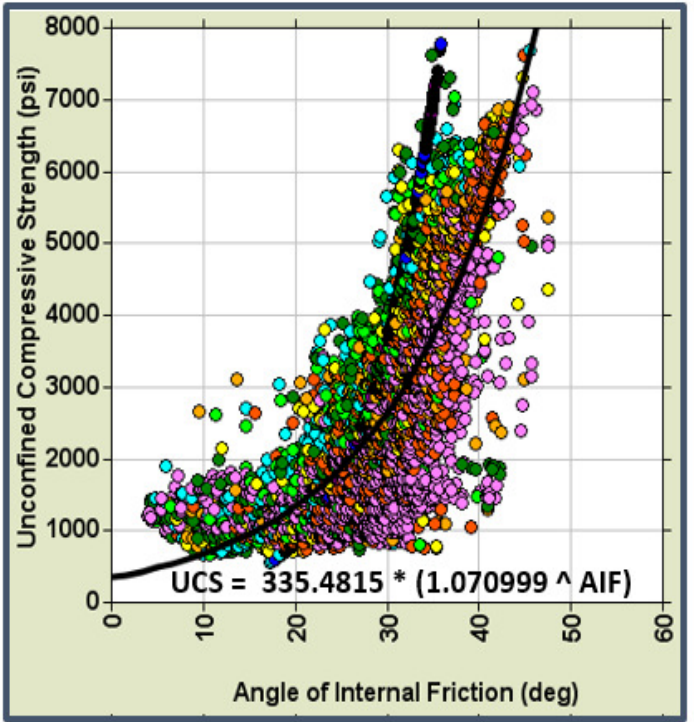

(a)

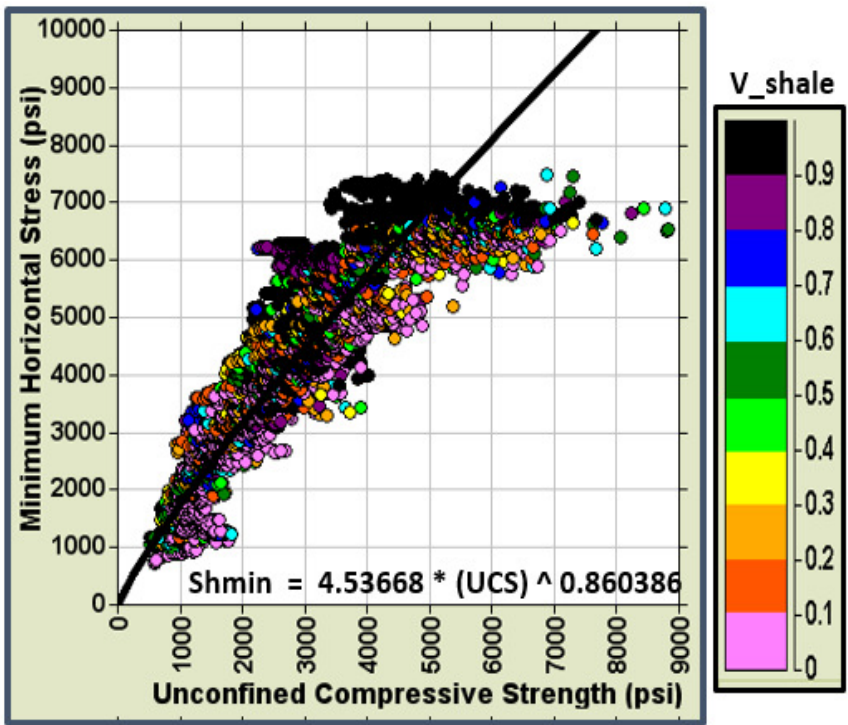

(b)

Figure 9: Relationship between Unconfined Compressive Strength and Angle of Internal Friction.

Rock strength parameters and in situ stress at key reservoir tops within the anisotropic interval are shown in Table 3.

Table 3. Stress and mechanical rock property data at key reservoir tops reservoir tops in the anisotropic interval.

\begin{tabular}{lccccccc}
\hline $\begin{array}{l}\text { TVDss } \\
(\mathrm{ft})\end{array}$ & $\begin{array}{c}\text { Top } \\
(\mathrm{deg})\end{array}$ & $\begin{array}{c}\text { AIF } \\
(\mathrm{psi})\end{array}$ & $\begin{array}{l}\text { UCS } \\
(\mathrm{psi})\end{array}$ & $\begin{array}{c}\text { PP } \\
(\mathrm{psi})\end{array}$ & $\begin{array}{l}\text { Shmin } \\
(\mathrm{psi})\end{array}$ & $\begin{array}{c}\text { SHmax } \\
(\mathrm{psi})\end{array}$ & OBP \\
\hline 6846 & RT_1 & 30.12 & 3698.72 & 2979.02 & 4839.26 & 5516.42 & 6259.80 \\
7307.5 & RT_2 & 30.63 & 3964.91 & 3178.85 & 5184.06 & 5909.52 & 6724.29 \\
7587 & RT_3 & 31.12 & 4232.30 & 3299.87 & 5696.02 & 6493.22 & 7007.52 \\
7759.5 & RT_4 & 27.06 & 3878.09 & 3374.56 & 5611.61 & 6396.97 & 7182.88 \\
8265 & RT_5 & 29.46 & 3380.06 & 3593.45 & 6047.33 & 6893.74 & 7699.95 \\
8506 & RT_6 & 33.07 & 4231.08 & 3697.80 & 6217.08 & 7087.27 & 7947.86 \\
8888.5 & RT_7 & 34.61 & 6669.72 & 3863.42 & 5898.13 & 6723.63 & 8343.10 \\
9176.5 & RT_8 & 34.00 & 6174.56 & 3988.12 & 6496.11 & 7405.39 & 8642.09 \\
9410.5 & RT_9 & 34.91 & 7612.59 & 4089.45 & 6607.61 & 7532.51 & 8885.75 \\
9915 & RT_10 & 33.94 & 6122.65 & 4307.89 & 6339.50 & 7226.85 & 9413.66 \\
\hline
\end{tabular}

Symbols: True vertical depth sub-sea, Angle of Internal Friction, Pore pressure, Minimum horizontal stress, Maximum horizontal stress, Overburden pressure (vertical stress)

Rock failure profiles estimated with the strength and in situ stress data are shown in Figure (10). The minimum safe drilling mudweight below which rock shear failure would occur decreases with depth in the well; the values range from $0.379 \mathrm{psi} / \mathrm{ft}$ to $0.684 \mathrm{psi} / \mathrm{ft}$. with an average of $0.529 \mathrm{psi} / \mathrm{ft}$ in the well, giving an average overbalance of $655 \mathrm{psi}$. The result shows that the overbalance is higher in the shale intervals than sands. On the other hand, the maximum safe drilling mudweight above which tensile failure would occur is estimated to range from $0.40 \mathrm{psi} / \mathrm{ft}$ to $0.783 \mathrm{psi} / \mathrm{ft}$, with an average of $0.713 \mathrm{psi} / \mathrm{ft}$. These figures suggest an average safe drilling mudweight window of $0.529 \mathrm{psi} / \mathrm{ft}$ to $0.713 \mathrm{psi} / \mathrm{ft}$ (Figure 10b) with an average optimum drilling mudweight of $0.621 \mathrm{psi} / \mathrm{ft}$. 


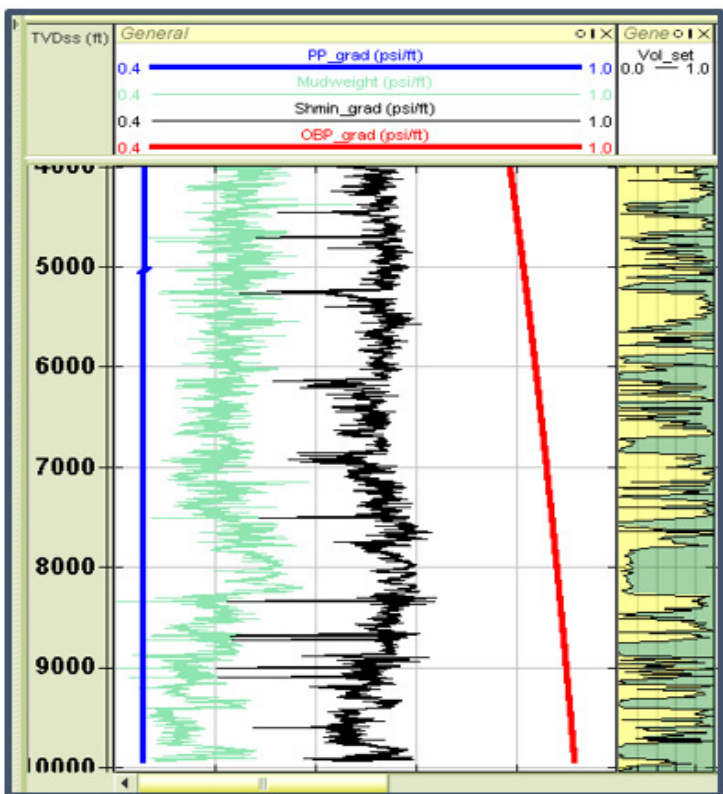

(a)

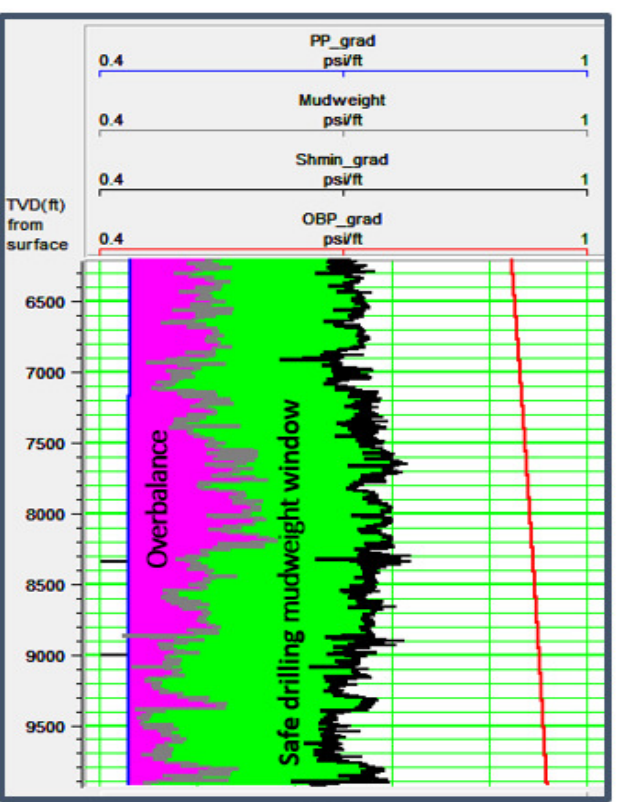

(b)

Figure 10: Rock failure and safe drilling analysis of XP2. (a) Track 1: (Pore pressure gradient, Blue; Minimum mudweight, Grey; Maximum mudweight, Black; Overburden pressure gradient, Red); Track 2: Lithologic vole set (b) Repeat plot emphasizing the safe mudweight window.

Finally, the results show that assuming isotropy for geomechanical characterization leads to underestimation of the rock's mechanical properties in subsurface intervals where there is presence of velocity anisotropy. As expected, the estimated in situ horizontal minimum stress is approximately same for the anisotropic and isotropic case, but is much lower for isotropic than the anisotropic case. Obviously, this has a resultant effect on the horizontal maximum stress and subsequently the predicted safe drilling mudweight and its window. Figure 11 a shows comparison of the minimum and maximum horizontal stress modeled assuming isotropy and using the vertical transverse isotropy model, and Figure $11 \mathrm{~b}$ compares the mudweight and minimum horizontal stress computed using the different models. The isotropic assumption resulted in the prediction of a much lower safe drilling mudweight window. This has a serious safety and cost implication. The results have underscored the need to consider velocity anisotropy in geomechanical characterization even though the procedure is evidently tedious. The workflow presented in this study is applicable to other depobelts in the Niger Delta and could be a good starting point for empirical modeling of rock's mechanical properties which could then be "ground-truth" with measured rock stress data. Table (4) shows comparison of the results of the isotropically and anisotropically modeled stress and mudweiht data at the reservoir tops.

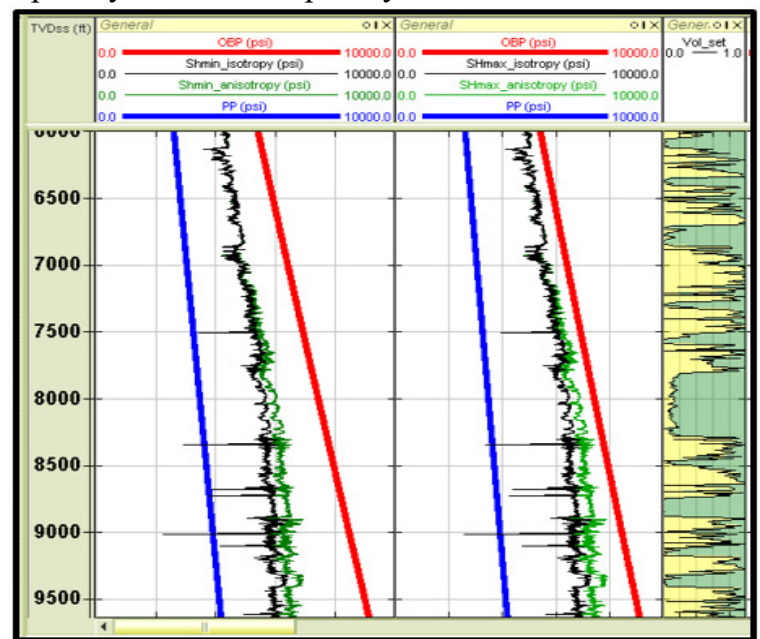

(a)

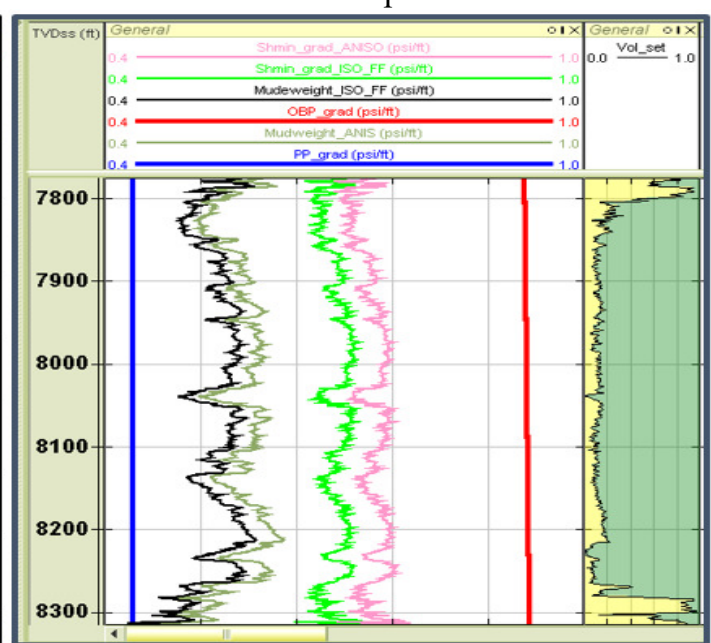

(b)

Figure 11: Minimum horizontal stress and drilling mudweight for XP2: (a) Track 1: (Pore pressure, PP - Blue; Isotropically modeled minimum horizontal stress (Shmin) - Black; Anisotropically modeled Shmin - Green,

Overburden stress (OBP) - Red; Track 2: PP - Blue; Isotropically modeled maximum horizontal stress (SHmax -Black); Anisotropic SHmax - Green); Track 3: Lithology. 
Table 4. Comparison of anisotropically modeled rock stress and safe drilling mudweight to the isotropic model.

\begin{tabular}{llcllccc}
\hline $\begin{array}{l}\text { TVDss } \\
(\mathrm{ft})\end{array}$ & Top & $\begin{array}{c}\text { MW_ANIS } \\
(\mathrm{psi} / \mathrm{ft})\end{array}$ & $\begin{array}{c}\text { MW_ISO ShG_ANIS ShG_ISO PP_Grad OBP_Grad } \\
(\mathrm{psi} / \mathrm{ft})\end{array}$ & $\begin{array}{l}\text { (psi/ft) } \\
(\mathrm{psi} / \mathrm{ft})\end{array}$ & $\begin{array}{l}\text { (psi/ft) } \\
(\mathrm{psi} / \mathrm{ft})\end{array}$ \\
\hline 6846 & RT_1 & 0.5096 & 0.5084 & 0.7069 & 0.7050 & 0.4351 & 0.9144 \\
7307.5 & RT_2 & 0.5093 & 0.5002 & 0.7094 & 0.6941 & 0.4350 & 0.9202 \\
7587 & RT_3 & 0.5286 & 0.5120 & 0.7508 & 0.7224 & 0.4349 & 0.9236 \\
7759.5 & RT_4 & 0.5382 & 0.5145 & 0.7232 & 0.6871 & 0.4349 & 0.9257 \\
8265 & RT_5 & 0.5595 & 0.5275 & 0.7317 & 0.6797 & 0.4348 & 0.9316 \\
8506 & RT_6 & 0.5257 & 0.4952 & 0.7309 & 0.6754 & 0.4347 & 0.9344 \\
8888.5 & RT_7 & 0.4314 & 0.4027 & 0.6636 & 0.6088 & 0.4347 & 0.9386 \\
9176.5 & RT_8 & 0.4720 & 0.4425 & 0.7079 & 0.6526 & 0.4346 & 0.9418 \\
9410.5 & RT_9 & 0.4388 & 0.4106 & 0.7022 & 0.6476 & 0.4346 & 0.9442 \\
9915 & RT_10 & 0.4476 & 0.4192 & 0.6394 & 0.5862 & 0.4345 & 0.9494 \\
\hline
\end{tabular}

Symbols: True vertical depth sub-sea, Mudweight (anisotropic), Mudweight (isotropic), Horizontal minimum stress gradient (anisotropic), Horizontal minimum stress (isotropic), Pore pressure gradient, Overburden pressure gradient

\section{Conclusion}

Majority of works on rock's mechanical property modeling carried out in the Niger Delta have largely assumed isotropy even though anisotropy is intrinsically present in the Niger Delta as a result of its geologic setting. In the foregoing, we characterized geomechanical rock properties in an exploration well in the shallow offshore depobelt of the Niger Delta, incorporating velocity anisotropy in the log-based modeling of the important geomechanical properties, namely the Young's modulus and Poisson's ratio. The study shows that whereas the shallow interval up to about $6,800 \mathrm{ft}$ tvdss is isotropic, the deeper interval is anisotropic. The modeled geomechanical properties are much higher in the horizontal direction than the vertical in the anisotropic interval, but track in the isotropic interval. Rock strength and in situ stress data modeled and analyzed in this study show that assumption of isotropy in geomechanical modeling results in under-estimation of rock strength and state of stress in situ. This is particularly important as it has serious safety and cost implication during exploration or production drilling. The results obtained from this study could assist the drilling engineer in planning safe and cost effective drilling of the well. Accurate determination of the rock strength and stress state results in the prediction of accurate safe drilling mudweight window to prevent shear and tensile failure with their resultant unpleasant effects during drilling. The workflow presented is applicable to other depobelts in the Niger Delta and could be a good starting point for empirical modeling of rock's mechanical properties which could thereafter be "ground-truth" with measured rock stress data.

\section{References}

Abijah, F.A. and Tse, A.C. (2016). Geomechanical evaluation of an onshore oil field in the Niger Delta, Nigeria. IOSR Journal of Applied Geology and Geophysics, vol. 4(1), p. 99-111.

Amadei, B., Savage, W.Z. and Swolfs, H.S. (1987). Gravitional stresses in anisotropic rock masses. Int, J. Rock Mech. Min. Sci. \& Geomech., 24, 5-14.

Archer, S. and Rasouli, V. (2012). A Log Based Analysis to estimate mechanical. petroleum and mineral resources, 163-170.

Avbovbo A. A. (1978). Tertiary Lithostratigraphy of Niger Delta: AAPG Bulletin, 62, 295-306. Evamy, B. D., Haremboure, J., Kamerling, P., Knaap, W. A., Molloy, F. A., \& Rowlands, P. H. (1978). The hydrocarbon habitat of the Niger Delta. American Association of Petroleum Geologists Bulletin, 62(1), 1-39.

Bassey A., Dosunmu, A., Olaseinde, B., Lonna, U. Buduka, S. and Madu, S. (2011). Geomechanical modelling of therma effects on wellbore stability using the thermos-poro-elastic model in HPHT wellbores. SPE150771, Abuja, Nigeria. August.

Burke K. (1972). Longshore drift, submarine canyons and submarine fans in the development of the Niger Delta. American Association of Petroleum Geologists Bulletin, 56, 1975-1983.

Chang, C., Zoback, M.D. and Khaksar, A. (2006). Empirical relations between rock strength and physical properties in sedimentary rocks. Journal of Petroleum Science and Engineering, 51, 223-237.

Coates, G.R. and Denoo, S.A. (1981). Mechanical properties program using Borehole Analysis and Mohr's circle, SPWLA, $22^{\text {nd }}$ Annual Logging Symposium.

Davies, D.H., Davies, O.A. and Horsfall, O.I. (2019). Determination of geomechanical properties of a typical Niger Delta reservoir rock using geophysical well logs. Asian Journal of Applied Science and Technology, 
vol. 3(1), 222-333.

Deere, D.U. and Miller, R.P. (1966). Engineering classification and indexing properties for intact rock. Technical Report no. AFWL-TR-67-114, Air Force Westpons Laboratpry, Kirtland, New Mexico.

Dosumu, A., (2014). The gamblers ruin - The driller's albatross. University of Port Harcourt Inaugural Lecture Series, No. 115. 2014.

Doust H., and Omatsola, E. (1990). Niger Delta. In J. D. Edwards \& P. A. Santogrossi (Eds.), Divergent/passive margin basins (pp. 239-248). American Association of Petroleum Geologists Bulletin Memoir 48.

Edlmann, K., Somerville, J.M., Smart, B.G.D., Hamilton, S.A. and Crawford, B.R. (1998). Predicting rock mechanical properties from wireline porosities, SPE/ISRM Europe, 47344, July.

Ejedawe, J. E. (1981). Patterns of incidence of oil reserves in Niger Delta Basin. American Association of Petroleum Geologists, 65, 1574-1585

Harry, T.A., Etuk, S.E., Inyang, N.J. and Okoli, E.A. (2018). Geomechanical evaluation of reservoirs in the coastal swamp, Niger Delta region of Nigeria. International Journal of Advanced Geosciences, vol. 6, no. 2 , $165-172$

Higgins, S.M., Goodwin, S.A., Donald, A., Bratton, T.R. and Tracy, G.W. (2008). Anisotropic stress models improve completion design in the baxter shale, Soc. Petrol. Eng., SPE- 115736-MS.

Horsrud, P. (2001). Estimating mechanical properties of shale from empirical correlations. SPE Drill. Completion, 16, 68-73.

Iqbal, O., Ahmad, M. and Askury Abd Kadir, A.P. (2017). Geomechanical characterization of potential roseneath shale gas, Cooper Basin, Australia. ARPN Journal of Engineering and Applied Sciences, vol. 12. no.2, 5221-5231.

Jones, I.F., Bernitsas, N., Farmer, P., Leslie, J. and Bridson, M. (2002). Anisotropic ambiguities. EAGE 64 Conference and Exhibition, Italy., May 2002

Jones, I.F., Bridson, M.L. and Bernitsas, N, (2003). Anisotropic ambiquities in TI media. First Break 21(4):2935. Jones, I.F. (2015). Estimating subsurface parameter fields for seismic acquisition: Velocity model building. U1-2 Encyclopedia of Exploration Geophysics, SEG.

Konstantinovskaya, E., Grachoe, O., Petakov, Y., Sobaley, A., Eremeev, A., Delia, S., Shadchney, Shtyfel, A., Parshin, N., Drandusov, K. and Yahunin, S. (2016).

Lal M. (1999). Shale stability: drilling fluid interaction and shale strength. SPE Latin American and Caribbean Petroleum Engineering Conference held in Caracas, Venezuela.

Lawson-Jack, O., Uko, E.D., Tamunobereton-Ari, I. and Alabraba, M.A. (2019). Geomechanical characterization of a reservoir in part of Niger Delta, Nigeria. Asian Journal of Applied Science and Technology, vol 3(1). 10-30.

McNally, G.H. (1987). Estimation of coal measures rock strength using sonic neutron logs. Geoexploration, 24 , 381-395.

Mody, F.K. Tare; Wang, G.G., (2008). Application of Geomechanics Technology in Borehole Stability Reduces Well Construction Costs. American Rock Mechanics Association - 08-255

Najibi, A. R., Ghafoori, M., Lashkaripour, G. R., \& Asef, M. R. (2015). Empirical relations between strength and static and dynamic elastic properties of Asmari and Sarvak limestones, two main oil reservoirs in Iran. Journal of Petroleum Science and Engineering, 126, 78-82

Ogagarue, D.O. and Ebeniro, J.O. (2018). Quantification and correction of the Thomsen's delta anisotropy for improved quantitative seismic interpretation in “ÄMFO” field, western Niger Delta, International Journal of Physical Sciences, vol 13(15), 230-234.

Pandey, R.A., Stress field delineation using well log data - case study. International Journal of Earth Science and Engineering, vol 6(1), 538-547.

Ramjohn, R., Gan, T. and Sarfare, M. (2018). 3D geomechanical modeling for wellbore analysis: Energy Resources Conference, SPE-191242-MS, Spain, June.

Reijers, T.J.A., Petters, S.W. and Nwajide, C.S. (1997). The Niger Delta Basin, in Selly, R.C. ed. African

Basins - Sedimentary Basins of the world. 3. Amsterdam, Elsevier Science, pp. 151-172.

Shorte, K.C. and Stauble, A.J. (1967). Outline of geology of Niger Delta. Bull. Amer. Assc. Petr. Geol. Vol 45 (5), 761-779.

Słota-Valim, M. (2015). Static and dynamic elastic properties, the cause of the difference andconversion methods-case study. Nafta-Gaz, 11, 816-826.

Steiner, S., 1996, IMPACT rock mechanical evaluation, Schlumberger Evaluation and Production Services, Gatwick, England.

Thiercelin, M.J. and Plumb, R.A. (1994). A core-based prediction of lithologic stress contrasts in east Texas formations, SPE Form. Eval. 9(4), 251-258.

Thomsen. L., 1986, Weak anisotropy, Geophysics, 51, 1954-1966.

Turtle M.L.W., Charpentier, R.R. and Brownfield, M.E., 1999, The Niger Delta Petroleum System: Niger Delta 
Province, Nigeria, Cameroun and Equatorial Guinea, Africa, Central Region Energy Resources Team, U.S. Department of the Interior, U.S. Geological Survey, Open Report, 99-50H.

Wang, Z. and Nur, A. (2000). Seismic and acoustic velocities in reservoir rocks, vol. 3. Recent Developments, Geophysics reprints series, 19, 8-23.

Wang, Z. (2002). Seismic anisotropy in sedimentary rocks, part 2, Laboratory data, 67, 1423- 1440.

Weingarten J.S. and Perkins, T.K. (1995), Prediction of sand production in gas wells: methods and Gulf of Mexico case studies. J. Petrol. Tech. 596-600.

Whiteman A., (1982). Nigeria: Its Petroleum Geology, Resources and Potential: London, Graham and Trotman,394 p.

Xiao, X., Jenakumo, T., Ash, C., Bul, H., Fakunle, O. and Weaver, S. (2016). An integrated workflow combining seismic inversion and 3D geomechanics modelling - Bonga Field, Offshore, Nigeria. OTC Conference, OTC-27108-MS, Houston, Texas, USA, May.

Xu, H., Zhou, W., Xie, R., Da, L., Xiao, C., Shan, Y., \& Zhang, H. (2016). Characterization of rock mechanical properties using lab tests and numerical interpretation model of well logs. Mathematical Problems in Engineering, 2016.

Yale, D.P. and Jamieson, W.J., Jr. (1994). Static and dynamic rock mechanical properties in the Hugoton and Panoma fields. Kansas Society of Petroleum Engineers, Paper 27939. SPE Mid-Continent Gas Symposium, Amarillo, TX, May.

Zamiran, S., Rafieepour, S. and Ostadhassan, M. (2018). A geomechanical study of Bakken Formation considering the anisotropic behavior of shale layers, Journal of Petroleum Science and Engineering, Vol. 165 , p. 567-574. 